\title{
Realismo y vanguardia en la poesía de Alejandro Rubio
}

\author{
Realism and avant-garde in Alejandro Rubio's poetry
}

\author{
MARTÍN BAIGORRIA ${ }^{a}$ \\ ${ }^{a}$ Consejo Nacional de Investigaciones Científicas y Técnicas. Argentina. \\ Correo electrónico: martin.rodriguezbaigorria@gmail.com
}

El artículo repasa los vínculos entre realismo y vanguardia en la obra de Alejandro Rubio, uno de los autores más prolíficos dentro de la poesía argentina de los noventa. Se destacan cuatro momentos: atención al deterioro social, manejo plástico del estereotipo, negación al nivel sintagmático, juego con la repetición y el sinsentido. Esas estrategias literarias se apoyan en distintos aspectos vinculados a la experiencia histórica del peronismo (tono revanchista, desconfianza frente al orden cultural, énfasis en el conflicto de clase, entre otros). La polémica es inmanente y temática, vanguardista y clásica a la vez: cada uso lingüístico, cada aspecto de la cultura pone en juego una serie de riesgos formales dirigidos contra cualquier versión sublimadora del discurso poético. Hay ahí implicado un programa crítico de alcance secular que hace de la lengua un objeto en disputa permanente.

Palabras claves: realismo, vanguardia, poesía de los noventa, peronismo.

This essays seeks to review the links between realism and avantgarde in Alejandro Rubio's poetry, one of the most prolifics authors in argentine nineties poetry. Within this realm four moments are emphasised: attention to social impoverishment, plastic use of clichés, negation proyected in the sintagmatic level of language, and a playfull use of repetition and non-sense. These literary strategies rely heavily on several aspects rooted in the peronist experience (social vindicteviness, mistrust on the cultural order, class-conflict, etc.). The controversies displaed by this poetical approach is thematic and inmmanent, classic and experimental: from this stand-point, every speech use, every cultural aspect (high or low) display a great number of formal risks aimed towards towards any sublime expression sedimented in the poetical speech. This gesture implies in itself a critical programm with a secular reach that transforms language in an object of permanent dispute.

Key words: realism, avantgarde, nineties argentine poetry, peronism. 


\section{REALISMO Y VANGUARDiA}

Al día de la fecha la obra de Alejandro Rubio abarca unos 15 libros publicados entre 1997 y $2019^{1}$. Los puntos de partida son el registro de la experiencia neoliberal y la crisis del peronismo durante la década del noventa; a partir de ahí se abrirán varias perspectivas que se ramifican y vuelven a confluir dentro de su escritura. Esa concepción del realismo se apoya en el objetivismo argentino y en la poética de Leónidas Lamborghini, junto a otras lecturas donde irán confluyendo Leopoldo Marechal, Alberto Girri, Joaquín Giannuzi, Juan José Saer, así como también distintos momentos de la poesía hispanohablante (desde Nicanor Parra y Virgilio Piñera hasta el siglo de oro) ${ }^{2}$. Pero ¡cómo se despliegan estos elementos dentro de su obra? Podría hablarse de un doble movimiento que va del realismo a la vanguardia y viceversa. Así por ejemplo, la pauperización de la clase trabajadora lleva las coordenadas del objetivismo -observación, compacidad del verso, léxico concreto, etc.hacia toda clase de énfasis grotescos o feístas, reforzados por esa misma técnica ${ }^{3}$. Mientras que, en un segundo movimiento, el riesgo formalista amplía una polémica donde ningún episodio de la doxa argentina pareciera quedar a resguardo. Gesto marginal o contrera, se dirá: aunque en rigor debería hablarse de una perspectiva peronista y lamborghineana dirigida hacia la cultura y las jerarquías de clase; en esa estrategia de negación generalizada hay un programa crítico que conviene examinar en detalle.

\section{Del lugar COMÚN AL REVANCHISMo}

Distintas variantes del realismo confluyen en la poesía de Rubio, provenientes de la literatura, el peronismo y el discurso de los medios de comunicación. Para el realismo moral, desde el Satyricon hasta Balzac, los intereses materiales y las pulsiones son el sustrato que marcan las acciones e ideas más nobles: en el caso de esta poesía, los niños cantan, bailan y ponen gilletes en los toboganes, un imitador de Baudelaire sale a "cazar hembras" en su Honda o alguien declara su amor ofreciendo quinientos euros, etc. ${ }^{4}$ (Rubio 2012: $74,313,322)$. Funciona ahí un designio clásico de la crítica que Rubio alinea con los contrastes más grotescos del realismo social. Pero la realidad puede ser también el discurso

\footnotetext{
${ }^{1}$ A esas publicaciones deben añadirse varias plaquetas: Personajes hablándole a la pared (1994), Wachiturros (2011, ensayos), Hablando de poesía con el tachero (2016), Not serbian (2017a). La última de ellas, Moral, fue publicada en 2021 por Ascasubi ediciones. Para más información ver la bibliografía al final de este artículo.

${ }^{2}$ Ver el prólogo de Ana Mazzoni incluido en La enfermedad mental-Poesía reunida- (Rubio 2012: 9-19).

${ }^{3}$ Esto ya fue señalado originalmente por Daniel García Helder en el Posfacio de 1997 a Música mala: "el motivo plebeyo de Música mala se opone a la técnica de su propia escritura” (García Helder 2012 [1997]: 23-36). En la antología La tendencia materialista (Mazzoni, Selci y Kesselman 2012) se retoma esa lectura.

${ }^{4}$ Salvo excepciones, las referencias a la poesía de Rubio corresponden a La enfermedad mental, volumen donde se halla compilada la mayor parte de su obra (Rubio 2012).
} 
de los medios de comunicación; más de una vez en esta poesía aparecen referencias a la televisión y la radio: imágenes estereotipadas, el sonido repetitivo de las noticias o la música comercial. "En palabras de Lou Reed (...) 'esta es la era de la violencia en video'. Y nosotros (...) queremos escribir una literatura que dé cuenta o al menos se dé cuenta del fin de la joda y de la violencia en video" (Rubio 2009a: 79). En términos de las filiaciones literarias, esta sería una forma de acercar al objetivismo a su contexto social más inmediato: en la época de los mass-media la imagen no puede ser concebida solamente como una impresión óptica aislada y etérea, sino también a partir del sensacionalismo o las simplificaciones transmitidas por la tecnología comunicacional de avanzada ${ }^{5}$. A eso apuntan también el feísmo, el trazo grueso expresionista o la resolución del poema con un verso contundente, fusionándose la estética del realismo social con la violencia del impacto mediático. Podría postularse entonces una doble determinación del discurso realista, aprehendido tanto en sus variantes literarias como en sus expresiones audiovisuales contemporáneas.

Pero también debe decirse que en más de un sentido esas combinaciones provienen del modo en que el peronismo entiende el lugar común. Esta es una cuestión clave en la poética de Rubio a la que cabe añadir un poco de perspectiva histórica. En la simbología oficial del justicialismo el estereotipo tiene un sentido necesario y positivo: refleja un conjunto de valores que en los términos de La comunidad organizada hacen posible el paso del yo al nosotros; una visión compartida del mundo y el hombre (desde la marcha peronista hasta las Veinte Verdades). Luego están los símbolos profanos donde los estigmas se convierten en marcas de identidad (los apelativos cabecita negra, descamisados, las patas en la fuente, etc.); una perspectiva excluida a partir de la cual se observa la realidad como un hecho impuesto violentamente por los sectores oligárquicos. En una línea similar, para escritores como Arturo Jauretche o Leopoldo Marechal la cultura es expresión de intereses socioeconómicos; sus gustos y saberes son también lugares comunes, zonceras que expresan una hegemonía de clase ${ }^{6}$. Es una posición distinta a la mirada de la izquierda ilustrada que encuentra en la cultura una oportunidad para elevar la sensibilidad de las masas (siempre retrógradas e ingenuas). El peronismo recela de esos valores e instituciones ante las cuales prefiere el chiste, la provocación o la simple indiferencia.

Se trataría de una actitud antropológica desinhibida: tras el halo sagrado de la cultura apenas queda un retablo de fetiches y tabúes artificiales; así por ejemplo mientras Marechal caricaturiza los tics de los intelectuales pertenecientes al grupo Sur, Leónidas

\footnotetext{
${ }^{5}$ En cuanto al uso o las referencias a los medios audiovisuales en la poesía, otras posibilidades pueden hallarse en Verme de Leónidas Lamborghini (1988), Punctum de Martín Gambarotta (1996) y Hatuchay (2005) de Washington Cucurto.

${ }^{6}$ Cabe agregar además que, a nivel histórico, estas tres concepciones de la realidad terminarán superpuestas con la proscripción del peronismo (1955-1973), quedando la primera muchas veces subordinada a las otras dos siguiendo la fórmula de Cooke: los símbolos se convierten en un "hecho maldito", el lugar de reconocimiento para la comunidad excluida-.
} 
Lamborghini hace su propia versión del himno nacional y La razón de mi vida ${ }^{7}$. En el caso de Rubio el tratamiento del cliché también puede adoptar una perspectiva cercana a esos autores: "(...) El, yo, los dos / (...) peinados / para la fotito, (...) / ficción pura: falta, nomás, como indicio / de un marco, una calle, una ciudad / país, mundo, etcétera, el ruido / de una alarma de un auto, o un perro minimalista / llorando bajo, lejos, sin hueso" (2012: 72-73). En esta écfrasis confluyen la puntuación saereana, el esquematismo de la reproducción técnica y el acento paródico de Osvaldo Lamborghini; por lo que tampoco sería errado ver ahí operando las variantes del realismo antes mencionadas.

Se comprueba así una predilección especial por el lugar común, citado y a la vez impugnado a través de distintos temas, imágenes o locuciones ${ }^{8}$. Pero mientras en Leónidas Lamborghini predomina el balbuceo y en su hermano Osvaldo el malentendido psicoanalítico", Rubio va a preferir la elocuencia: “(...) está lleno / de sátiros que bajan de las colinas / en tropel para estorbar el tráfico / y dibujar muecas de buzón en las viejas / que se exprimen los limones y sacan jugo / amarillo de saber y de cinismo" (2012: 286). Esos "sátiros" que bajan "en tropel" para interrumpir el orden normal de las cosas convierten al tópico dionisiaco en una arcilla expresiva, quedando patas para arriba el criterio de clase que ponía de un lado la pobreza, el mal y lo desagradable, frente a la belleza, el bien y la sabiduría. Por otro lado, la exasperación que descubre una "mueca de buzón" en las señoras resalta otro aspecto singular en la obra de Rubio: el odio de clase como un componente de la identidad peronista, sentimiento nunca del todo asumido por la doctrina y relegado después de 1983 que sin embargo aparece con insistencia en esta obra:

\footnotetext{
7 "Leónidas Lamborghini me gusta por dos razones: porque (...) sabe que la literatura de un país periférico no puede medirse con los mismos criterios de calidad que los productos europeos. Acá no hay dos mil quinientos años de civilización que sostengan las acrobacias de las vanguardias y no hay curso acelerado que valga: somos analfas y bárbaros y debemos asumirlo con alegría, positivamente. (...) Segundo, porque ha encontrado una figura que condensa esa posición: la deformidad" (Rubio 2010b: 44-45). En cuanto a esto último, una perspectiva similar ya estaba anunciada al final de Adán Buenosayres: "Más feo que un susto a medianoche. Con más agallas que un dorado. Serio como bragueta de fraile. Más entrador que perro de rico. De punta, como cuchillo de viejo. Más fruncido que tabaquera de inmigrante. Mierdoso, como alpargata de vasco tambero. (...)" (Marechal 1966: 644). En Prosas cortas se ofrece una respuesta al libro de Marechal: "El cadáver de un perro amenaza a los émulos de Dante y no hay guías a mano" (2012: 175).

${ }^{8} \mathrm{Si}$ bien en los estudios más tradicionales los lugares comunes constituyen vicios expresivos que empobrecen al lenguaje, más recientemente han surgido otros abordajes cercanos a la perspectiva de este trabajo. Amossy $\&$ Herschberg-Pierrot sostienen por ejemplo que estas son representaciones hechas sobre esquemas culturales preexistentes que permiten asimilar la realidad cotidiana. Siguiendo las reflexiones de Walter Lipmmann, esas imágenes serían indispensables para la vida en sociedad (Amossy y Herschberg-Pierrot 1997: 26). Sobre la cuestión del lugar común en la literatura peronista, valga el comentario de Ana María Zubieta sobre Adán Buenosayres: "Marechal hace de esas formas congeladas del decir y de la verdad, de esas formas solidificadas y espesas de la cultura, una de las materias de sus novelas y, así, pone de manifiesto más que el origen de la verdad, su naturaleza lingüística, cultural (...) la violencia de haber sido hecha por los otros, para los otros" (Zubieta 1997: $116,121)$. Creo que una preocupación similar es atribuible a la poética de Rubio.
}

${ }^{9}$ Para un análisis en detalle del tema, Marimón 1989; González 1998; Porrúa 2001. 
A veces fantaseo, con los adolescentes que se insultan entre sí por costumbre, con una música que acompase cada pie en la marcha arcaica hacia la capital desdeñosa y con fuego en Recoleta, con artistas de tevé empalados que al Señor rueguen por la continuidad de sus depósitos. (2012: 156$)^{10}$

Para una sensibilidad poco beligerante esta fantasía puede resultar extraña ya que ese odio siempre habría pertenecido al otro: las clases medias y las elites antiperonistas identificadas con el prejuicio gorila ${ }^{11}$. Pero al menos durante la época de la proscripción, ¿no es dicho tono una marca reconocible en el discurso peronista de izquierda? ${ }^{22}$ No puede sin embargo esperarse en la poesía de Rubio el gesto de la rabia o la indignación; de manera similar al realismo, el odio de clase se halla descompuesto en una variedad de sentimientos negativos: resentimiento, agresividad, deseo de revancha, etc.; mientras que aquellos otros de signo positivo, más familiares para la tradición lírica, aparecen puestos en cuestión.

Esto último sería también parte de una discusión cultural, particularmente subrayada por la "poesía de los noventa": de qué modo se habla sobre aquellos sentimientos mal vistos o relegados por las formas convencionales del género y cómo sus expresiones más

\footnotetext{
${ }^{10}$ También en Prosas cortas: "En Nomepiyé lo bello se convierte en feo y viceversa. (...) No puede haber nada más armonioso que cualquiera de estos negros mugrientos metiéndole un choclo en el culo a la Pati y después comiéndose una hamburguesa con huevo, lechuga y tomate provenientes de una quinta como la de él" (2012: 166).

${ }^{11}$ Tampoco la izquierda, en términos generales, dedicó mucha atención al concepto: se trataría de un sentimiento individual, a la larga improductivo, que debe ser dejado de lado en favor de la lucha de clases. Para Errico Malatesta ahí radicaba la diferencia entre "pueblo" y "proletariado": "Hágase cuánta lucha de clase se quiera (...) Pero odio no, porque del odio no puede surgir el amor y la justicia. Del odio nace la venganza, el deseo de sobreponerse al enemigo, la necesidad de consolidar la propia superioridad. Con el odio, si se vence, se pueden fundar nuevos gobiernos, pero que no se puede fundar la anarquía” (Malatesta 1923). Walter Benjamin sugiere sin embargo lo contrario; el odio de clase es un elemento necesario de la lucha que surge de la identificación de los trabajadores con todas las opresiones del pasado: “(...) la clase desaprendió lo mismo el odio que la voluntad de sacrificio. Pues ambos se nutren de la imagen de los antepasados esclavizados y no del ideal de los descendientes liberados" ("Sobre el concepto de historia" [Tesis XII], Benjamin 1996: 59). Como suele suceder en Benjamin, esa identificación de los antepasados con la idea general del sufrimiento humano no deja de tener connotaciones religiosas.

${ }^{12}$ Los documentos compilados por Roberto Baschetti darían cuenta de ello. Por otro lado no es exagerado hallar rastros de la prosa de John William Cooke en el estilo de Rubio: “(...) una regencia de bayonetas que tutela los privilegios de dentro y de fuera exige la remisión de un prisionero de guerra que escapó a sus guardias de hierro. Las saturnales revanchistas son catarsis para estas ciudadelas del Occidente Imperial (...)" (Baschetti 1988: 272). Para un estudio de ese contexto histórico, James 1990.
} 
decorosas construyen imágenes idealizadoras del hombre ${ }^{13}$. Pero la preocupación es también política: para el Rubio lector de Nietzsche y Mao, los sentimientos que mueven la voluntad y llevan a la acción suponen entre otras cosas el deseo de revancha, la voluntad de vencer al enemigo o la necesidad de consolidar la propia superioridad ${ }^{14}$; lejos de ser estériles esas afecciones también serían herramientas necesarias e inevitables de la acción colectiva. Por eso en "Los derechos del ciudadano" "(...) el chasquido de un cargador / cuando entra en la pistola es para mí / la música más maravillosa, preñada / de pasado y futuro" (2012: 287). A Rubio no le interesa denunciar el discurso de un sujeto de derecha sino más bien resaltar cómo esa violencia latente habita en la mente del ciudadano de a pie, quien de una manera u otra participa de esos deseos y rencores asociados al odio de clase ${ }^{15}$.

Debe agregarse además que el sintagma "la música más maravillosa" -proveniente del último discurso de Perón- aparece numerosas veces dentro de esta obra, hecho que evidencia otra cercanía con la poesía de Leónidas Lamborghini. De manera similar a este último la fraseología del peronismo se convierte en una materia ubicua, como puede verse en otro momento clásico de ese discurso, el "asado con parquet" ${ }^{16}$ :

Porque vimos el futuro donde el piso es de parqué y rompemos el parqué pa que se dore más lindo. (68)

Las tablas del parqué son teclas de un piano mecánico que nunca funcionó. Afuera, el tiempo con su marchita. Y todas esas cabezas calvas pelando un huevo.

(...) el parqué espejeante cuando ella suda y trasiega y suda.

(2012: 68, 165, 168)

En estos ejemplos la palabra "parqué" funciona al menos en tres niveles semánticos cuyas contradicciones aluden a la memoria histórica de los trabajadores durante la etapa

\footnotetext{
13 "el resentimiento es combustible" (Gambarotta, 2004: 73). En el rock argentino posterior a la dictadura también había surgido esa preocupación: "Idiota perdido aquel que no se reconozca en un odio insensato" (Miguel Abuelo, "Buen Día, Día”).

${ }^{14}$ Ver la cita a Malatesta en la nota 5.

${ }^{15}$ Lo curioso es que, como en otros momentos de su poesía, esta reivindicación de la violencia juega con varios registros a la vez, exasperando los tópicos y combinándolos con una fabulación intelectual exótica, ajena a la tipología del desclasado: “(...) la libertad es la pelea / infinita entre titanes que se tumban y se levantan / y son su propio público salvo el ojo / de Moloch abierto para siempre / detrás de una cumbre nevada y una estrella sardónica" (2012: 287).

${ }^{16}$ Es un lugar común de la crónica diaria: "Los argentinos ańosos recuerdan la leyenda urbana que parieron esos pisos de parquet, en hábitat de buena calidad, distribuidos masivamente con sensibilidad social. Se dijo y repitió por décadas que los cabecitas negras que los recibieron levantaban el parquet para hacer asados. El mito gozó de buena prensa y divulgadores masivos de clases medias y altas. (...)" ("El asadito en el parquet". Wainfeld 2012).
} 
neoliberal iniciada en los noventa: i. estigma, ii. elemento de redención violenta con todos los componentes de la venganza de clase y, por último, símbolo de un bienestar raquítico -el suelo cotidiano donde desembocan las aspiraciones de progreso social ${ }^{-17}$. Como puede verse en estos desplazamientos -más allá incluso de sus simpatías estéticas o políticasla perspectiva de Rubio frente al peronismo es anti-mitológica; no se trata de evocar el pasado sino de reflexionar sobre la situación actual de dicha lengua (sus simbologías, contradicciones, etc.). Por eso vale en este punto una comparación con otras artes: mientras un artista como Daniel Santoro pinta la comunidad idealizada del primer peronismo donde reinaron el goce y la felicidad, Rubio dirige la atención hacia el presente recuperando el lado más antipático de esa identidad política.

\section{De La Negatividad a La REPETICIÓN}

Se trataría así de una poesía marcada por el "espíritu revanchista llevado a todos los niveles de la escritura y el objeto literario"18. Como ya indicaba García Helder (2012 [1997]), esto puede notarse particularmente en el plano sintagmático, donde la negación se impone como principio compositivo. Puede ser mediante imágenes opuestas: "Algo que combine / fichas de juego y madonas de ojos grandes, / el roce de marquesas tomando té / (...) / y la táctica de tierra arrasada: / el gordo hablando a las doce en el baño de la estación”. A nivel fonético, paronomasia mediante: “(...) vetas / del texto que al develar / defenestran (...)"; "Los pasajeros / son pasajeros". O jugando con la pausa versal: "(...) adictos a los deportes de riesgo / y hemipléjicos frente al televisor (...)" (2012: 49, 55, 306). Este uso de la compacidad objetivista subraya la tensión de sus elementos internos, como si en cada sintagma una dimensión lingüística fuera a ser discutida por otra mediante distintas connotaciones sarcásticas, irónicas, etc. ${ }^{19}$. Así, en un libro como Rosario (2005) cada referencia pueda quedar descompuesta en una miríada de asociaciones críticas o humorísticas que suelen presuponer una discusión con los gustos literarios del momento, los prejuicios sociales o los mitos seculares de la burguesía local. Pero ya en Música mala (1997) las figuras literarias de autoridad eran examinadas desde la perspectiva de la coyuntura socio-económica:

Esos, los de antes, decían que, sobre todo

en la autopista y en, de noche, las bocas tapiadas

del subte nuevo, algo parecía

moverse.

\footnotetext{
${ }^{17} \mathrm{Tal}$ vez no sea irrelevante que la palabra posea un origen francófono.

${ }^{18}$ Entrevista de Martín Rodríguez, "El peronismo es un gran revelador” (Rodríguez 2010).

${ }^{19}$ Esa preeminencia de lo negativo puede reconocerse inmediatamente en los títulos de sus libros. Véase el apartado FUENTES.
} 
Efectivamente se movía.

La capital de Suroccidente es ahora una grande y hermosa

ruina; entre pilares

de monumentos fachosoviéticos se pasean filigranas

humosas, turistas, periodistas, carteristas,

animales de una y tres patas. Los rapsodas ciegos

se recuestan en vergeles virtuales y chuponean cigarrillos

virtuales, es así, el viento tañe solo entre las hojas.

Está el ritmo, las letras, partes sueltas

de melodías, arreglos mil, pero ante el público

se les traba la lengua, callan, dicen no saber,

no poder, no querer; se consuelan con eso

de que la Historia, émula del tiempo, testigo

de lo pasado, ejemplo y aviso

de lo presente, advertencia...

(“La vida y el canto", 2012: 59)

Con todos sus detalles apocalípticos y bizarros la escena enmarca una segunda operación crítica: los guiños polémicos a Juan José Saer, Juan L. Ortiz y Borges caricaturizan el tono de una reflexión intelectual que a partir de los noventa gira con fuerza hacia la historiografía ${ }^{20}$. A diferencia del Pierre Menard..., el juego con la cita cervantina de la "Historia, émula del tiempo, testigo de lo pasado" es otro capítulo de la doxa, mera repetición ya sin novedad alguna que en el discurso intelectual funciona como un placebo ${ }^{21}$. La supuesta perspectiva histórica destinada a proveer un mayor nivel de reflexividad desemboca en una escena de frustración colectiva: “(...) ante el público / se les traba la lengua, callan, dicen no saber / no poder, no querer". La lengua del intelectual entregada a la mirada historicista termina sumida en un balbuceo, con la misma retórica del alfonsinismo tras su salida anticipada del poder $^{22}$.

\footnotetext{
${ }^{20}$ Sobre el giro hacia el pasado valga esta reflexión de Gerárd Wajcman incluida en su ensayo El objeto del siglo: "Parece (...) que lo que en otro tiempo fue un pequeño artesanado de la memoria habría prosperado (...) hasta el punto de alcanzar hoy las dimensiones de la gran industria. Memorial Company. (...) Del éxito de las disciplinas de la Historia (...) al fervor conmemorativo, pasando por la explosión de un mercado del pasado (...), (¡Ante Todo No Perder Nada! -fantasma mezquino) (...) ¡Gloria al pasado! ¡Honra a los padres!” (Wajcman 2001: 16-17).

${ }^{21}$ Vale recordar también el comentario de García Helder: “(...) las líneas del Quijote de Menard citadas en 'La vida y el canto' fueron acondicionadas con algunas sustracciones que (...) a nivel semántico se tornan reveladoras: entre lo descartado se cuenta nada menos que 'la verdad', 'las acciones' y 'lo por venir' (...)" (García Helder 2012 [1997]: 32). La cita proviene del "Ensayo de lectura de Música mala" incluido tanto en dicho libro como en La enfermedad mental-Poesía reunida- (Rubio 2012).

${ }^{22}$ La referencia al discurso alfonsinista es otro uso sarcástico del estereotipo. Así mismo, puede hallarse una variación de esta escena -protagonizada esta vez por la intelectualidad peronista- en "El conferenciante" (Metal
} 
Se retoma así aquella crítica de las letras y el espíritu elaborada por Jauretche ${ }^{23}$. Según este último dicho discurso sería un símbolo ilusorio de estatus, incapaz de modificar la realidad; diagnóstico que en el contexto neoliberal irá adquiriendo figuraciones cada vez más esperpénticas:

Dos cadáveres se sientan a la mesa

y agarran los cubiertos; se miran

con ojos blancos, y de sus bocas sin labios

se escapa una letanía:

aieoooooo... aeioooooooooooo...

Proposición categórica A: todo S es P;

proposición categórica I: algún $\mathrm{S}$ es $\mathrm{P}$;

proposición categórica $\mathrm{E}$ : ningún $\mathrm{S}$ es $\mathrm{P}$;

proposición categórica $\mathrm{O}$ : algún $\mathrm{S}$ no es $\mathrm{P}$.

Nada más puede decirse.

No dicen más

las masas en sus casas, cuando termina

la cena y el brillo del televisor

los atrae como a moscardones el sol de noche.

(2012: 89)

En estos últimos versos aparece un tema de la crítica marxista -la reproducción de las condiciones de dominación a nivel social e ideológico ${ }^{24}-$ que constituye una preocupación importante para esta poesía, otra vuelta de tuerca en torno a los problemas del realismo contemporáneo: al no poder evocarse ya una voluntad, memoria o expectativa de futuro, queda la cuestión de cómo presentar la naturalización de esas circunstancias al nivel de la subjetividad cotidiana. La cuestión de la conciencia es, por otro lado, una preocupación importante en la corriente objetivista, particularmente clara en autores como Girri o Gianuzzi ${ }^{25}$, que Rubio retomara en sus propios términos: "El Servicio acaba de informar / que el sol de la Justicia pegará todo el día / sobre todas las cabezas, y sobre todo la mía / se

pesado, 1999): "El conferenciante se vuelve loco de repente, / se arranca los pelos, se pone a vociferar: / “ila Historia! ¡ la Historia / ¡la flecha de la Historia!" / Algunos entre el público / saludan con los dedos en V. / Pero ya quedó demostrado / que la flecha no se mueve" (2012: 111).

${ }^{23}$ Esa lectura de Jauretche se encuentra en el ensayo de Rubio "Antiintelectualismo" (2014: 76-79). Para más referencias véase Los profetas del odio y la yapa (la colonización pedagógica) (Jauretche: 1957) y el segundo apartado de este artículo.

${ }^{24}$ Una referencia clásica es el ensayo de Louis Althusser “Ideología y aparatos ideológicos del Estado" (Althusser $1988[1970])$.

${ }^{25}$ El problema de la conciencia histórica tampoco sería ajeno a la poesía de Lamborghini ("Me detengo un momento / por averiguación de antecedentes". Lamborghini 1989 [1971]: 9). 
parte en cuatro o más (...)" (2012: 70). La locución "el Sol de la justicia" es otro ejemplo de lugar común utilizado para subrayar el efecto de repetición característico de los medios masivos. La expectativa de reparación social es idéntica a una realidad rutinaria y estática que, lejos de motivar, desarticula toda capacidad de reflexión. Reiteración de costumbres y valores, reinicio perpetuo del orden dominante; desde esa perspectiva las buenas intenciones apenas son insumos del ciclo reproductivo conducido por las fuerzas del capital. Rubio mantiene ese diagnóstico a lo largo de su obra. Todo horizonte de progreso, individual o colectivo, cualquier expectativa de liberación queda reducida a una misma alternancia ${ }^{26}$ : "el tiempo pasado hacía / el tiempo presente que se estanca en fétido cieno / y obtura el tiempo futuro jamás" (2012: 391) ${ }^{27}$.

Puede hacerse entonces una comparación con otro poeta contemporáneo: si en Poesía civil Sergio Raimondi pone el énfasis en las contradicciones de la identidad nacional, ya sea a nivel económico, idiomático o territorial, la preocupación de Rubio pasa por la conciencia; se trata de describir su situación tomando como punto de partida la eliminación de esos conflictos históricos en el "más allá de la patria soberana" (Rubio 2004: 37), cuando el peronismo pierde sus coordenadas doctrinarias y se transforma en un aparato de poder. Sería al menos una hipótesis a tener en cuenta: constantemente los vínculos entre realidad y subjetividad, formas y contenidos, se juzgan a partir de las contradicciones irresueltas u olvidadas de la nación ${ }^{28}$.

\section{De La RePetición a la Vanguardia}

Pero si el peronismo se niega a sí mismo, si la conciencia del trabajador ya no encuentra el sentido de la historia y queda atrapada en la repetición (mediática o existencial), de ese balance surgirá un gesto de negación más amplio. En los libros posteriores -Prosas

\footnotetext{
${ }^{26}$ Antes que un plan preconcebido, la justicia sería un acto destructivo surgido a la manera de una descarga pulsional: "Así andamos, introduciendo un poco de ruido en el sistema, nosotros, corruptores y héroes, embarrados hasta la verija y sonrientes de cara a la primera lluvia de primavera” (2012: 166).

${ }^{27}$ Así también en Diario: "Gordo, desdentado, tragando vino de la casa, tragando aire, jadeando, entre alumnos, idiotas, que escuchan, apenas, lo que alguna vez fue la verdad, pero repiten, prolijamente, para el futuro, palabras huecas" (Rubio 2009a: 34). Otros ejemplos: "La información" (57), "Clavale el pico en la cabeza al huevero" (68), "Un rápido vistazo", "El Oeste" (110), "Acto" (324), "El desubicado" (337), "El guardabarrera” (342). "Técnica del poema social" (344), etc. Los textos donde los personajes asumen una perspectiva transformadora son escasos: "Carta abierta" (79), "Nostalgia" (317) o el poema "un solo sexo para todos y a dejarse / de joder" (379) incluido en Nociones para un lechón (Rubio 2012). Que esa perspectiva sea abordada con la voz de un personaje ajeno a la retórica de la crítica "progresista" o de "izquierda" es otro aspecto a tener en cuenta. Otro ejemplo sería "El soldado Manning" que comentamos con más detalle en la sección siguiente de este artículo.

${ }^{28}$ El poema "El guardabarrera" puede leerse como un diálogo con otro de Raimondi incluido en Poesía civil, "El verbo inglés ante la acción del fuego" (2010 [2001]: 22): "La resistencia de los materiales nobles / al agua y al fuego por desgracia no se transmite / a los encajados en una estructura de ladrillo y fierro, / fanáticos cebadores de mate y adictos al tabaco sin filtro" (Rubio 2012: 342).
} 
cortas (2003), Foucault (2006), Falsos pareados (2008)- la repetición y la falta de sentido, antes registrada al nivel de la subjetividad, pasará desde el contenido al plano formal:

Cínico en Cenareso cepilló

el lomo de una boa y el letrista de la Mona

arrancó pezones con un destapador.

La estructura perfecta de los alerones del Spitfire.

La estructura perfecta de las películas de Spielberg.

La perfecta de Alejandra Pizarnik.

La estructura de Harrison Ford.

La rara mezcla de un fotograma del Potemkin con un horóscopo de chicle Bazooka.

(2012: 171, 217, 219, 221)

Se toma una estructura verbal en apariencia "rígida" (tercetos, "pareados", sonetos, estructuras sintácticas, etc.) y se las somete a todo tipo de variaciones: humor absurdo, juegos fonéticos, mezclas de vocablos exóticos y giros orales, más escenas grotescas ${ }^{29}$. Sobre el rol de los medios masivos Rubio es tan pesimista como Juan José Saer o Theodor Adorno, pero a diferencia de estos su estilo asume esa alienación convirtiéndola en un material lingüístico en sí mismo: si a nivel mediático o existencial la realidad se produce mediante el retorno de lo mismo, esa repetición puede convertirse de distintas maneras en un gesto vanguardista.

Así por ejemplo, en el caso de "El soldado Manning" la monotonía se exacerba y prescinde incluso del humorismo. Se impone un versículo con tono de letanía:

La conciencia.

La conciencia como punto.

La conciencia como punto intenso.

La conciencia como punto intenso lumínico.

La conciencia como punto intenso lumínico que escruta la res.

La conciencia como punto intenso lumínico que escruta la res. [explorando sus secretos.

La conciencia como punto intenso lumínico que escruta la res explorando sus secretos que son la

[voluntad de Dios.

(2018a: 47)

\footnotetext{
${ }^{29}$ En el caso de las prosas compiladas en Diario (2009a) la variedad temática también se organiza en torno a un procedimiento de repetición formal: la entrada de un supuesto diario íntimo fijada a una misma fecha, como si se tratara de una especie de eterno retorno porteńo.
} 
El tema de fondo es la traición a la corporación militar a la cual pertenecía Manning. Pero los énfasis de este drama filosófico ya no se construyen con aquella sofisticada compacidad de inspiración anglosajona que había llegado hasta Rubio desde Eliot, Girri y García Helder, sino mediante la pura repetición de un sintagma que va agregando complementos gramaticales de la manera más previsible. La cuestión de género (implícita en el título del poema) tampoco es ni siquiera aludida: la transformación se remite al tema de la conciencia protestante, asunto que no es motivo para la efusión retórica o intelectual. El planteo es contra-intuitivo. La decisión se escenifica mediante el discurso más lineal; ella no surge de ninguna convulsión interna, sino del avance rectilíneo del sintagma ajeno a cualquier sorpresa o expectativa: el cambio subjetivo es un cortocircuito producido por las invariantes de la lengua.

Al igual que con el realismo o el odio de clase, hay un punto entonces en que la poética de Rubio descompone sus elementos nucleares para reorganizarlos del modo más aleatorio ${ }^{30}$. El caso más ambicioso sería Foucault. Como indica Mazzoni, son textos concebidos a partir de la convergencia arbitraria de tres ejes: "la primera parte es una reformulación de un proverbio popular, la segunda es una oración que detalla una situación espacial y la tercera es una cita casi textual de Las palabras y las cosas" (2012: 16-17). Cada uno de esos momentos supone una reescritura de intereses literarios y no literarios previos: la reformulación del proverbio popular puede referirse tanto a esa conciencia aplanada que caracteriza su retrato de las clases populares como a su versión combativa ${ }^{31}$; las imágenes de la mirada objetiva desembocan en el exotismo lumpenizado; mientras que las citas del filósofo francés evocan con suma incoherencia el talante reflexivo de dicha poética o de la poesía culta en general ${ }^{32}$. La diversidad y el rango de los interlocutores explicita el método general de esta poética: en un mismo texto caben disparos en simultáneo hacia la situación social o política, puntualísimas alusiones al debate literario y plagios al posestructuralismo. El juego arbitrario con esos sintagmas sería otra estrategia peronista orientada a relativizar el prestigio de la alta teoría; qué hacer con las ideas de un pensador francés cuando estas devienen retórica de salón: copiarlas descaradamente, trocearlas, convertirlas en vacío manierismo formalista en lugar de fetichizarlas con la cita reverente y previsible.

Las polémicas planteadas en Música mala y Metal pesado continúan así en los libros experimentales: ya sea la tradición lírica (desde la Odisea hasta la música de Pastoral), la figura

30 El absurdo por ejemplo reaparece en los poemas de la línea objetiva -como puede verse en el libro Sobrantes (2010a)-: "Hasta que uno, el más sabio o el más tonto / o uno que no se sabía si era o se hacía / (...) / (...) pronunció las palabras mágicas / y nos adentramos más hacia el este, / hacia el río de león que si no llevaba / un raviol llevaba un canelón” (2012: 310-311).

31 Algunos ejemplos: "El gaucho como el quijote no se engaña / cuando ataca de frente los molinos del monopolista”, "Ni tierra ni pan ni justicia: / son campanas de palo los cencerros de las vacas" (2012: 209, 212).

${ }^{32}$ A modo de precedentes o influencias, también cabe mencionar la poesía de Daniel Samoilovich: “Creyó que veía la Transa / de Medio Kilogramo; / miró mejor y vio que era / un Paralelogramo. / "Así los dos perdemos -dijo-, / ¿por qué no vamo'y vamo'?”. El título del poema dice: “LO QUE SE CREE VER / Y LO QUE REALMENTE ES / (Y LO QUE AL NOTARLO, DIJO)” (Samoilovich 2014 [1996]: 156). 
de Roberto Bolaño o la hegemonía cultural de Estados Unidos. Con toda su gratuidad, esa destrucción del aura proyectada por los nombres célebres de la cultura es un aspecto central en la escritura de Rubio que, una vez más, no excluye los sentimientos asociados al odio de clase: "Infatuados ilotas cascando nueces sobre cabezas de sabios que desde abajo los miran humillados" (2012: 180).

La dialéctica del amo y el esclavo queda así invertida y junto con ella la estructura social del saber. No sería exagerado pensar que esos "infatuados ilotas" se enfrentan a la cultura como un montón de basura -restos híbridos sin jerarquías posibles entre sí-, acercándose así a la visión que Scalabrini Ortiz proponía para la comprensión de la realidad argentina: "El alma de los pueblos brota de entre sus materialidades, así como el espíritu del hombre se enciende entre la inmundicias de sus vísceras" (2001 [1940]: 5). Esto sería algo inevitable en un país ajeno a las grandes corrientes de la literatura mundial. Muchas veces se pensó que esa falta podía suplirse con la tesis de Borges que reclamaba el derecho de la periferia a la tradición universal; pero para autores como Lamborghini o Rubio dicho acervo no es una premisa clave sino un material a reciclar según las necesidades del contexto argentino. Si la libertad irrespetuosa reclamada por Borges entrańaba la fantasía de una cómoda cercanía a la tradición de Occidente - con acceso directo a sus bienes más refinados-, para Rubio esto solo supone libre manipulación de los desechos: “(...) ¿Está bien si yo digo / la cabeza y los dones y los usos / y los dioses y vidas y fortunas / y naturas me han sido entregados / para que los tome como quien tome una cosa / de la que siempre se dice sin temor 'úsela y / tirelă: lo dicen todo el tiempo / 'sí: / úsela y tirela'?' (2012: 119-120).

\section{Polémica Clásica y Vanguardista}

Así podrían resumirse los cuatro momentos que en esta poesía marcan la dialéctica de realismo y vanguardia: percepción del deterioro social, manejo plástico del estereotipo, negación al nivel sintagmático, juego con la repetición y el absurdo. Todo esto le permite a Rubio un énfasis polémico sin equivalentes en la literatura argentina, más amplio y arriesgado si lo comparamos con otros precedentes como David Viñas o Rodolfo Fogwill. El diagnóstico surgido en la década de los noventa se expande desde el presente hacia el pasado; al igual que con la identidad de la clase trabajadora, nada queda de la cultura o la tradición: "la patria es caca / y todos nosotros fecales somos" (2012: 301). Incluso aunque para la izquierda nacional haya un pasado a ser rescatado, poetas como Lamborghini o Rubio son menos optimistas: si sobrevive, serán escombros antes que un horizonte de sentido a restituir mediante relatos y conmemoraciones. Se redobla así -por paradójico que parezcael planteo de Jauretche: la nación es un proyecto inconcluso, sus símbolos e instituciones meras figuritas de papel. La identidad queda reducida a pura arcilla, por igual maleable en manos de los grandes capitales, las ideologías y la literatura de turno.

Pero cabe ver también en ese diagnóstico terminal un programa de mayor alcance. $\mathrm{O}$ al menos así entiende Rubio la discusión del peronismo con la cultura: cuando se deshace 
su aura de universalismo, sus grandes símbolos y axiomas funcionan también con la violencia de una pantalla, estereotipos visuales, sonoros o léxicos que delimitan el día a día de la conciencia. Rubio usa entonces esos elementos como formas e ideas descompuestas; cada rasgo lingüístico se ve mediado por un gesto negativo dirigido a crear un estado de polémica permanente. La intención clásica de la crítica - confrontar las ideas con la realidad- se redobla con un planteo vanguardista que apunta a producir un estado de agitación en todos los momentos de la lengua, ya sea al nivel de la poesía, los medios masivos, o las formas ideales del arte y el pensamiento. Esto marca una diferencia con esa cultura de izquierda que logró resistir en democracia apoyándose en los meandros del pasado -a través de la historiografía, la genealogía, las conmemoraciones, etc.-. Y también frente a un ambiente literario donde la noción dominante de crítica se reduce al elogio, la efeméride o el resumen melifluo. Rubio no encaja dentro de ese panorama. Pese a todas las derrotas, se propone una alternativa a una maquinaria cultural acostumbrada a la cautela o los gestos testimoniales. El cuestionamiento a los bienpensantes se convierte en una controversia secular, un ataque al orden cristalizado en los usos de la lengua. A mediano o largo plazo es la mayor apuesta de su obra.

\section{Obras Citadas}

\section{FUENTES}

Cucurto, Washington. 2005. Hatuchay. México D.F.: Ediciones el billar de Lucrecia. Gambarotta, Martín. 1996. Punctum. Buenos Aires: Libros de Tierra Firme. 2004. Relapso + Angola. Bahía Blanca: Vox.

Lamborghini, Leónidas. 1988. Verme. Buenos Aires: Editorial Sudamericana. . 1989 [1971]. El solicitante descolocado. Buenos Aires: Libros de Tierra Firme.

Lamborghini, Osvaldo. 1988. Novelas y cuentos. Barcelona: Ediciones del Serbal.

Marechal, Leopoldo. 1966. Adán Buenosayres. Buenos Aires: Compañía Impresora Argentina.

Raimondi, Sergio. 2010 [2001]. Poesía civil. Bahía Blanca: 17grises editora.

Rubio, Alejandro. 1994. Personajes hablándole a la pared. Buenos Aires [edición de autor]. . 1997. Música mala. Bahía Blanca: Ediciones Vox. 1999. Metal pesado. Buenos Aires: Editorial Siesta. 2003. Prosas cortas. Santiago de Chile-Mar del Plata: Ril editores/Melusina. 2004. Novela elegíaca en cuatro tomos. Ediciones Vox: Bahía Blanca. 2005. Rosario. Buenos Aires: Gog y Magog. 2006. Foucault. Buenos Aires: Imprenta Argentina de Poesía. 2008. Falsos pareados. Buenos Aires: Imprenta Argentina de Poesía. 2009a. Diario. Santiago de Chile (Chile): Libros La calabaza del diablo. 2009b. Samuel Horribly. Buenos Aires: Imprenta Argentina de Poesía. 
. 2010a. Sobrantes. Buenos Aires: Gog y Magog.

2010b. La garchofa esmeralda. Buenos Aires: Mansalva.

. 2011. Wachiturros. Buenos Aires: Spiral Jetty.

. 2012. La enfermedad mental-Poesía reunida-. Buenos Aires: Ediciones de Gog y

Magog.

. 2014. "Antiintelectualismo". En Revista Mancilla 7: 76-79.

2015. Kohan. Bahía Blanca: Ediciones Vox.

2016. Hablando de poesía con el tachero. Buenos Aires: Belleza y Felicidad.

2017a. Not serbian. Buenos Aires: Ascasubi.

2017b. El poema no es el tema. La Plata: Club Hem editores.

2018a. Iron Mountain. Rosario: Iván Rosado.

2018b. Moral. Buenos Aires: Ascasubi.

Samoilovich, Daniel. 2014 [1996]. Rusia es el tema. Poemas reunidos 1973-2008. Buenos Aires: Bajo la Luna.

Scalabrini Ortiz, Raúl. 2001. Política británica en el Río de la Plata. Buenos Aires: Editorial Plus Ultra.

\section{Bibliografía CRÍTICA}

Althusser, Louis. 1988 [1970]. Ideología y aparatos ideológicos del Estado. Freud y Lacan. Buenos Aires: Nueva Visión.

Amossy, Ruth y Herschberg Pierrot, Anne. 1997. Stéréotipes et clichés. Langue, discours, societé. Paris: Nathan.

Baschetti, Roberto. 1988. Documentos de la resistencia peronista 1955-1970. Buenos Aires: Puntosur.

Benjamin, Walter. 1996. La dialéctica en suspenso. Fragmentos sobre la historia. Santiago de Chile: Universidad ARCIS - Lom Ediciones.

Dobry, Edgardo. 2016. "Una mitología para la 'rechota democracia' Argentina: 'Carta abierta' de Alejandro Rubio". Bulletin of Hispanic Studies 6: 609-616.

Eliot, Thomas Stearn. 2000 [1942]. "La música de la poesía”. En Ensayos escogidos. México D.F.: Universidad Nacional Autónoma de México.

García Helder, Daniel. 2012 [1997]. "Ensayo de lectura de Música mala" [posfacio en la edición original del libro publicada por VOX]. En Alejandro Rubio La enfermedad mental-Poesía reunida-. Buenos Aires: Gog y Magog. 23-36.

González, Ricardo. 1998. La poesía de Leónidas Lamborghini. Buenos Aires: Ediciones Leos.

James, Daniel. 1990. Resistencia e integración. El peronismo y la clase trabajadora argentina 1946-1976. Buenos Aires: Editorial Sudamericana.

Jauretche, Arturo. 1957. Los profetas del odio y la yapa (la colonización pedagógica). Buenos Aires: A. Peña Lilo Editor.

Ledesma, Germán. 2017. "Alejandro Rubio: régimen político de un imaginario mediático”. El taco y la brea 6: 86-113. 
Malatesta, Errico. 1923. “¿Lucha de clases u odio de clases?: 'Pueblo' y 'proletariado”. El Sembrador: semanario politico y literario. 37.

Marimón, Antonio. 1989. "La seducción del gesto". Punto de Vista 36: 30-32.

Mazzoni, Ana, Selci, Damián y Kesselman, Violeta. 2012. La tendencia materialista. Antología crítica de la poesía de los noventa. Buenos Aires: Paradiso.

Mazzoni, Ana. 2012. "Prólogo a Poesía reunida". En La enfermedad mental. Buenos Aires: Gog y Magog, 2012: 9-19.

Porrúa, Ana. 2001. Variaciones vanguardistas. La poética de Leónidas Lamborghini. Rosario: Beatriz Viterbo.

Rodríguez, Martín. 2010. "El peronismo es un gran revelador" [entrevista a Alejandro Rubio]. En Noticias Urbanas. Buenos Aires (Argentina).

https://www.noticiasurbanas.com.ar/noticias/8f4c3dcd5366e634ea73f387a7ec9025/

Wainfeld. Mario. 2012. "El asadito en el parquet". En Página12. Buenos Aires (Argentina). https://www.pagina12.com.ar/diario/elpais/subnotas/197134-59492-2012-06-24.html Wajcman, Gérard. 2001. El objeto del siglo. Buenos Aires: Amorrortu.

Zubieta, Ana María. 1997. "Lugares comunes de la cultura nacional". En Walter Bruno Berg y Markus Klaus Schäffauer (eds.). Oralidad y argentinidad: estudios sobre la función del lenguaje hablado en la literatura argentina. Tübingen: Narr. 114-121. 